\title{
Zika virus: oral healthcare implications
}

Keywords: Arboviruses, Zika virus, Epidemiology, Oral, Dental.

Jair Carneiro Leão, ${ }^{1}$ Luiz Alcino Gueiros, ${ }^{1}$ Giovanni Lodi, ${ }^{2}$ Narendran Andrew Robinson, ${ }^{3}$ Crispian Scully ${ }^{4}$

1- Oral Medicine Unit, Departamento de Clínica e Odontologia Preventiva, Universidade Federal de Pernamuco, Recife, Brazil

2- Dipartimento di Scienze Biomediche, Chirurgiche e Odontoiatriche.

Università degli Studi di Milano

3- Discipline of Oral and Maxillofacial Surgery, Faculty of Dentistry, National University of Singapore, Singapore.

4- WHO Collaborating Centre for Oral Health- General Health; and UCL, London, UK

\section{\#Corresponding Author:}

Prof. Jair Carneiro Leão, PhD

Programa de Pós-Graduação em Odontologia

Av. Prof. Moraes Rego, 1235, Recife-PE, Brazil

CEP: $50.670-901$

jleao@ufpe.br 


\section{Abstract}

Zika virus (ZIKV) infection has been recognized since 1947, but just recently it became a worldwide major public health problem. The most common features of ZIKV infection are fever, cutaneous rash, arthralgia, and conjunctivitis but most affected patients with the clinical disease present with only mild symptoms. However, severe neurologic complications have been described: there is an occasional association with Guillain-Barre syndrome, and emerging data indicate an association between vertical transmission of ZIKV infection and microcephaly but no specific orofacial manifestations have yet been reported. ZIKV is present in body fluids and has also been demonstrated in the saliva, but there is as yet no reliable evidence to support ZIKV transmission via this pathway. Transmission in oral healthcare should be effectively prevented using standard infection control measures. There are currently no specific treatments for ZIKA virus disease and no vaccines available, so prevention of ZIKV is based on vector control. 


\section{Introduction}

Infection with Zika virus (ZIKV), a flavivirus was a neglected tropical disease with limited geographic spread until its major epidemic potential was highlighted during a large-scale outbreak in the Pacific Island of Yap in 2007 (Duffy et al., 2009). Several species of Aedes spp. mosquitoes have been incriminated as vectors of ZIKV, including Aedes aegypti.

The most common features of ZIKV clinical infection are fever, cutaneous rash, arthralgia, and conjunctivitis. ZIKV had not been known to cause severe disease or hospitalisations until an outbreak in French Polynesia in 2013-2014, when there were reports of neurological and auto-immune complications, such as Guillain-Barre syndrome (GBS) (Cao-Lormeau et al., 2016). Brazil declared a national public-health emergency in November 2015 after officials there noted a sharp increase in cases of microcephaly in newborns. Recent data also suggest an association between ZIKV infection and meningoencephalitis (Carteaux et al., 2016).

Faced with this emerging scenario, governments and public health authorities are establishing strategies to control ZIKV infection and limit its potential complications. To increase the awareness of this health problem, the World Health Organisation (WHO) has recently made available an app, "WHO Zika App", which provides for health care workers, the latest information on ZIKV (http://www.who.int/risk-communication/zika-virus/app/en/).

\section{Epidemiology of ZIKV}

ZIKV was first isolated from a sentinel rhesus monkey placed in the Ugandan Zika Forest in 1947. A second isolation from the mosquito Aedes africanus followed at the same site in 1948. Since then, sporadic ZIKV isolations have been made from humans and a variety of mosquito species both in Africa and Asia, supported by seroprevalence studies in humans and animals (Haddow et al., 2012). It is possible that ZIKV may have undergone recombination in nature and, after emerging in Uganda, it spread to West Africa and Asia, without any clear preference for any host or vector species (Faye et al., 2014). Nevertheless, it has been shown the various ZIKV strains are genetically very similar to each other with strong conservation overall (Haddow et al., 2012). 
The first human ZIKV infection was reported in 1957, and the first large Zika outbreak in humans was in 2007, on the Pacific Island of Yap, Micronesia, where nearly $73 \%$ of people were infected. However, between 2013-14, ZIKV outbreaks then were reported in other Pacific Islands of French Polynesia, Easter Island, Cooks Island and New Caledonia (Kindhauser et al., 2016). In April 2015, researchers at the Federal University of Bahia in Brazil reported the identification of ZIKV RNA in 8 out of 25 Brazilian samples tested. This was then followed by reports of ZIKV in Camaçari (BA state [Bahia]), Natal (Rio Grande do Norte state), São Paulo (SP) state and Sumaré region (SP). Currently, ZIKV is widespread particularly in Latin America but since January 2007, 66 countries worldwide have reported outbreaks of ZIKV disease and as of 11 May 2016, 58 countries and territories report continuing mosquito-borne transmission (http://www.who.int/emergencies/zika-virus/situation-report/12may-2016/en/).

However, the true incidence of ZIKV infection is unknown, as symptoms may be subclinical, unrecognised or mimic those of other arboviral flavovirus diseases such as chikungunya and dengue and there has been a lack of a widely available inexpensive, simple, reliable laboratory diagnostic test for ZIKA.

Given the worldwide spread of chikungunya and dengue, associated with urbanization and globalization, there is a potential risk of outbreaks of ZIKV infection in urban settings in any part of the world where the mosquito vectors are present or become established in future. Figure 1 highlights the countries affected by ZIKV and the year of the first described case in each place.

\section{Modes of transmission of ZIKV}

The ZIKV natural transmission cycle in urban and suburban environments is human-mosquito-human, involving mosquitoes of especially Aedes species. Aedes aegypti and Aedes albopictus are responsible for the large majority of ZIKV outbreaks investigated.

According to the latest WHO situation report (11 May 2016), person-to-person transmission of ZIKV has been documented in 9 countries, probably via a sexual route. The perinatal transmission has also been described, and the potential for transfusion-transmitted infection exists (Musso et al., 2014). Besnard et al. (2014) described the clinical and laboratory features of two 
mothers and their newborns who had ZIKV infection confirmed by ZIKV RNA detection in serum collected four days post-partum. ZIKV particles have been demonstrated in breast milk, although to date, transmission via this route has not been reported (Dupont-Rouzeyrol et al., 2016). Infectious ZIKV has been detected in semen and transmission by heterosexual and homosexual routes has been demonstrated, reinforcing the need of using condoms especially for sexual activities during pregnancy (D'Ortenzio 2016). ZIKV RNA has also been detected in urine at higher loads and with a longer duration than in serum, as well as being found in amniotic fluid, placental or foetal tissues in several cases of nervous system malformations, including microcephaly (Dupont-Rouzayrol et al., 2015). ZIKV has been demonstrated in cell culture from the saliva of an Italian patient who had visited the Dominican Republic (Barzon 2016), and a monkey bite has been proposed as a plausible route of transmission, and ZIKV RNA has been detected in saliva from patients with Zika fever (Musso et al., 2015) but there as yet no reliable evidence to support ZIKV transmission through human saliva (Siqueira et al, 2016). In addition, the most updated data (April 26) regarding countries with confirmed local transmission are reported in table 2.

\section{Clinical and laboratory features of ZIKV disease}

ZIKV infection is believed to be asymptomatic or mildly symptomatic in most cases. The incubation period ranges from 2 to 7 days. Symptoms can last for up to a week, with a clinical presentation similar to that of other arbovirus infections such as chikungunya and dengue. The most common signs and symptoms of ZIKV infection are rash, self-limiting acute fever, arthralgia, myalgia, headache, and conjunctivitis. The rash is most often maculopapular and pruritic. Haemorrhagic signs are uncommon (Duffy et al., 2009). In contrast to acute dengue cases, ZIKV patients only rarely present mild thrombocytopenia and leucopenia, and metabolic dysfunction is not commonly observed (Kutsuna et al., 2014).

Occasionally, sore throat, cough, vomiting, diarrhoea and aphthous-like oral ulcers have been reported (Tappe et al., 2014; Foy et al., 2011). The oral ulcers in ZIKV have not been well documented in reports although they have been noted to appear on the lip mucosa (Foy et al., 2011) and apparently was a 
common presenting complaint in the French Polynesian outbreak of 2013 (http://www.npr.org/sections/goatsandsoda/2016/02/09/466152313/zika-in-

french-polynesia-it-struck-hard-in-2013-then-disappeared). There are very limited data indicating additional oral changes associated with ZIKV illness (Scully and Robinson 2016; Shakib 2016).

Risk groups for ZIKV infection include patients living in or returning from any of the many ZIKV affected areas, presenting with a fever or 'dengue-like' syndrome and testing negative for DENV. In this context, symptomatic pregnant women and their newborns should be tested for ZIKV (Besnard et al., 2014). ZIKV diagnosis can be based on multiple tests. Serology through detection of IgM against ZIKV by ELISA (Enzyme Linked Immuno-Sorbent Assay) is a costeffective option and cross-reacting antibodies with other flaviviruses can be differentiated by the plaque reduction neutralisation test for Zika antibodies. Nevertheless, IgM ELISA is expected to be positive by the end of the first week of infection and few laboratories have this facility (http://www.cdc.gov/zika/hcproviders/diagnostic.html). Laboratory confirmation of ZIKV infection is based mostly on detection of virus RNA in serum, using real-time Reverse Transcription Polymerase Chain Reaction (rRT-PCR). Urine samples may be used in less than 14 days of symptomatic disease for ZIKV RNA detection.

\section{Disease associations of ZIKV}

\section{Microcephaly and Birth Defects (Congenital Zika Syndrome)}

Microcephaly refers to a small head size (below -2 standard deviations) for the gestational age and sex. To date, microcephaly, and other foetal malformations potentially associated with Zika virus infection or suggestive of congenital infection, have been reported in seven countries or territories. Two cases, each linked to a stay in Brazil, were detected in Slovenia and the USA. One additional case, linked to a stay in Mexico, Guatemala and Belize, was in a pregnant woman in the USA (http://www.who.int/emergencies/zikavirus/situation-report/12-may-2016/en/).

The microcephaly clusters in Brazil have captured the attention of WHO and the world's media, given that $98 \%$ of cases have been reported from there. During late 2015, the Brazilian Ministry of Health began reporting an unusual increase in cases of microcephaly, first, in Pernambuco state, in north-eastern Brazil, 
then in 3 other states. On Nov $11^{\text {th }} 2015$, Brazil declared a national public health emergency and began undertaking clinical, laboratory, and ultrasound analysis of affected newborn babies and their mothers. Data indicate that From $22^{\text {nd }}$ October 2015 to $9^{\text {th }}$ April 2016, 7015 suspected cases of microcephaly (or other neurological abnormalities of newborns) have been reported. Among these, 1,113 have been confirmed ZIKA, 3,836 cases are still under investigation, and 2066 cases discounted, either because they did not fit standardised criteria for microcephaly or were attributable to other causes (Ministry of Health, Brazil [http://www.paho.org/hq/index.php?option=com_content\&view=article\&id=1159 9\&ltemid=41691\&lang=en]). Although the accuracy of microcephaly data has been questioned in the past (Butler, 2015), with enhanced surveillance, standardised and consistent case definitions, protocols and guidelines, current emerging data reflects more accurate reporting (http://www.paho.org/hq/index.php?option=com content\&view=article\&id=1111 7\&ltemid $=41532$ \&lang $=e n$ ).

Separately, a prospective study of ZIKV infected pregnant women has demonstrated high rates of foetal abnormalities on ultrasonography with adverse outcomes including foetal loss and microcephaly (Brasil et al., 2016). None of the ZIKV-negative women had any foetal abnormalities. There are shared peptides between ZIKV proteins and altered human proteins in microcephaly and brain calcifications, strengthening the link between ZIKV and neurological complications (Lucchese and Kanduc, 2016).

Furthermore, ZIKV abrogates neurogenesis, and its demonstration in foetal brain tissue, strengthens the link between ZIKV infection and microcephaly (Garcez et al., 2016), as does the fact that dengue virus targets only human brain cells. Besides microcephaly, other abnormalities reported with congenital ZIKV infection include low birth weight, redundant scalp skin, facial disproportionality, swallowing defects, hypertonia/spasticity, tremors/convulsions and hearing defects (Miranda-Filho Dde et al., 2016). Arthrogryposis, a rare disease characterised by a severe deficiency in the joints (Oliveira-Melo et al., 2016) and ocular abnormalities (optic nerve hypoplasia, chorioretinal atrophy, focal pigment mottling of the retina) have also been described in ZIKA affected newborns (de Paula Freitas et al., 2016). It is 
unclear as to how the craniofacial and other defects noted may evolve and impact the growing child in future years.

A recent review assessing available data on the basis of both the Shepard's Criteria for Proof of Teratogenicity in Humans (see Table 1) and the Bredford Hill Criteria, concluded that current evidence is sufficient to establish ZIKV as a teratogen (Rasmussen et al. 2016).

\section{Guillain-Barre syndrome (GBS)}

GBS is an acute paralytic peripheral neuropathy characterized by nerve inflammation and demyelination probably secondary to the action of antibodies against myelin antigens. GBS is often triggered by a viral infection, including dengue. GBS can be a life-threatening disorder with a mortality of 3-7\%, mainly from pulmonary complications or respiratory failure (Willison 2016). As of April 2016, 13 countries had reported an increase in GBS cases in ZIKV infection (WHO, 2016). ZIKV-associated GBS was first noted in French Polynesia in 2013-14, where 42 patients ( $72 \%$ male) were diagnosed with GBS, of whom 41 $(98 \%)$ had IgM or IgG antibodies against ZIKV. All GBS cases had neutralising antibodies to ZIKV and $88 \%$ had symptomatic ZIKV infection before the onset of neurological symptoms, supporting a causal link between ZIKV and GBS. Electrophysiological findings were compatible with the acute motor axonal neuropathy subtype of GBS. Although $38 \%$ of patients were admitted to intensive care for swallowing difficulties or respiratory assistance, no deaths were reported (Cao-Lormeau et al., 2016).

Research has demonstrated the existence of extensive peptide sharing between ZIKV and altered human proteins related to demyelination and axonal neuropathies, typical of GBS (Lucchese and Kanduc, 2016). Immune cross reactivity (molecular mimicry) leading to autoimmune processes may thus predispose to GBS.

\section{Prevention of ZIKV transmission}

Like many vector-borne diseases, the absence of vaccines and specific treatment against ZIKV means prevention and control are largely based on vector control and standard control of cross-infection methods. Prevention against mosquito bites (particularly daytime bites) is best offered by leaving skin 
as little exposed and covered with mosquito repellents. Icaridin provides up to 10 hours of protection and has been the first option for adults and pregnant women. Repellents are not recommended for use on babies younger than 2 months old; oil of lemon eucalyptus or para-menthane-diol repellents are not recommended for children younger than 3 years old.

Other prevention measures, include the elimination of mosquito breeding sites, limiting travel to affected areas, avoiding unprotected sex and taking precautions to avoid the risk of transfusion-transmission of ZIKV, for example by deferring potential blood donors returning from affected areas (http://www.cdc.gov/mmwr/volumes/65/wr/mm6512e3.htm, http://www.cdc.gov/zika/transmission/blood-transfusion.html).

The Butantan Institute in San Paulo, Brazil along with two other laboratories connected to the Brazil health ministry, and the U.S. government is also working on vaccines. One approach is a DNA-based vaccine involving a newer technique that injects a piece of the viral DNA rather than a protein fragment of the virus to stimulate the immune system. The other is known as a "live attenuated" approach, which uses a version of attenuated live ZIKV.

\section{Management of ZIKV infection}

Zika virus infection typically results in a relatively mild and self-limiting clinical illness. With the lack of specific treatment, infected individuals should be given adequate rest and hydration, and fever reduction using paracetamol rather than aspirin and non-steroidal anti-inflammatory drugs (NSAIDs).

ZIKA-infected people should avoid mosquito bites, abstain from unprotected sex, delay pregnancy and not donate blood (WHO, CDC, 2016).

ZIKV may be present in the saliva but there is as yet no reliable evidence to support ZIKV transmission via this body fluid. Transmission in the healthcare setting, including oral health, should be effectively prevented using standard infection control measures.

(http://www.cdc.gov/oralhealth/infectioncontrol/guidelines/).

\section{CONCLUSIONS}


$\mathrm{ZIKV}$ is a new emerging viral infection with global health repercussions. There is strong scientific consensus that ZIKV is the cause of microcephaly, GuillainBarré syndrome and some other neurological disorders. Additional surveillance and research studies are needed to improve our understanding of this disease, including the potential epidemiologic and clinical consequences of ZIKV cocirculation with other flaviviruses. The risk of transmission in the healthcare setting is low and should be effectively prevented by following standard infection control measures. 


\section{REFERENCES}

1- Barzon L, Pacenti M, Berto A, Sinigaglia A, Franchin E, Lavezzo E, Brugnaro P, Palù G (2016). Isolation of infectious Zika virus from saliva and prolonged viral RNA shedding in a traveller returning from the Dominican Republic to Italy. Euro Surveill. 2016;21(10).

2- $\quad$ Besnard M, Lastère S, Teissier A, Cao-Lormeau VM, Musso D (2014). Evidence of perinatal transmission of Zika virus, French Polynesia, December 2013 and February 2014. Euro Surveill 19:pii=20751.

3- Brasil P, Pereira JP Jr, Raja Gabaglia C, Damasceno L, Wakimoto M, Ribeiro Nogueira RM, Carvalho de Sequeira P, Machado Siqueira A, Abreu de Carvalho LM, Cotrim da Cunha D, Calvet GA, Neves ES, Moreira ME, Rodrigues Baião AE, Nassar de Carvalho PR, Janzen C, Valderramos SG, Cherry JD, Bispo de Filippis AM, Nielsen-Saines K (2016). Zika Virus Infection in Pregnant Women in Rio de Janeiro - Preliminary Report. N Eng J Med (in press). Doi: 10.1056/NEJMoa1602412.

4- $\quad$ Butler D (2015). Microcephaly surge in doubt. Nature 530: 13-14.

5- Cao-Lormeau VM, Blake A, Mons S, Lastère S, Roche C, Vanhomwegen J, Dub T, Baudouin L, Teissier A, Larre P, Vial AL, Decam C, Choumet V, Halstead SK, Willison HJ, Musset L, Manuguerra JC, Despres P, Fournier E, Mallet HP, Musso D, Fontanet A, Neil J, Ghawché F (2016). Guillain-Barré Syndrome outbreak associated with Zika virus infection in French Polynesia: a case-control study. Lancet 6736: 562-66. Doi: 10.1016/S0140-6736(16)00562. 6- $\quad$ Carteaux G, Maquart M, Bedet $A$, Contou D, Brugières $P$, Fourati $S$, Langavant LC, Broucker T, Brun-Buisson C, Leparc-Goffart I, Dessap AM (2016). Zika Virus Associated with Meningoencephalitis. Doi:

10.1056/NEJMc1602964.

7- de Paula Freitas B, de Oliveira Dias JR, Prazeres J, Sacramento GA, Ko Al, Maia M, Belfort R Jr (2016). Ocularfindings in infants with microcephaly associated with presumed Zika Virus congenital infection in Salvador, Brazil. JAMA Ophthalmol. doi: 10.1001/jamaophthalmol.2016.0267. [Epub ahead of print 
8- D'Ortenzio E, Matheron S, de Lamballerie X, Hubert B, Piorkowski G, Maquart M, Descamps D, Damond F, Yazdanpanah Y, Leparc-Goffart I. Evidence of Sexual (2016) Transmission of Zika Virus. N Engl J Med. [Epub ahead of print] DOI: 10.1056/NEJMc1604449 PubMed PMID: 27074370.

9- Duffy MR, Thane Hancock W, Kool JL, Lanciotti Robert S, Pretrick M, Marfel M, Holzbauer S, Dubray C, Guillaumot L, Griggs A, Bel M, Lambert AJ, Laven J, Kosoy O, Panella A, Biggerstaff BJ, Fischer M, Hayes EB (2009). Zika Virus Outbreak on Yap Island, Federated States of Micronesia. N Engl J Med 360:2536-43.

10- Dupont-Rouzeyrol M, O'Connor O, Calvez E, Gourinat AC (2015).

Detection of Zika Virus in Urine. Emerg Infect Dis 21: 84-86. Doi: 10.3201/eid.140894.

11- Dupont-Rouzeyrol M, Biron A, O'Connor O, Huguon E, Descloux E (2016). Infectious Zika viral particle in breastmilk. Lancet Mar 12;387(10023):1051. doi: 10.1016/S0140-6736(16)00624-3. Epub 2016 Mar 2. 12- Faye O, Freire CCM, lamarino A, Faye O, Oliveira JVC, Diallo M, Zanotto PMA, Sall AA (2014). Molecular Evolution of Zika Virus during Its Emergence in the 20th Century. PLoS Negl Trop Dis 8: e2636.

Doi:10.1371/journal.pntd.0002636.

13- Foy BD, Kobylinski KC, Chilson Foy JL, Blitvich BJ, Travassos da Rosa A, Haddow AD, Lanciotti RS, Tesh RB (2011). Probable non-vector-borne transmission of Zika virus, Colorado, USA. Emerg Infect Dis 17: 880-2 14- Garcez PP, Loiola EC, Madeiro da Costa R, Higa LM, Trindade P, Delvecchio R, Nascimento JM, Brindeiro R, Tanuri A, Rehen SK (2016). Zika virus impairs growth in human neurospheres and brain organoids. Science (in press).

15- Haddow AD, Schuh AJ, Yasuda CY, Kasper MR, Heang V (2012). Genetic Characterization of Zika Virus Strains: Geographic Expansion of the Asian Lineage. PLoS Negl Trop Dis 6: e1477.

Doi:10.1371/journal.pntd.0001477.

16- Kindhauser MK, Allen T, Frank V, Santhana RS \& Dye C (2016). Zika: the origin and spread of a mosquito-borne virus [Submitted]. Bull World Health Organ E-pub: 9 Feb 2016. doi: http://dx.doi.org/10.2471/BLT.16.171082 
17- Kutsuna S, Kato Y, Takasaki T, Moi ML, Kotaki A, Uemura H, Matono T, Fujiya Y, Mawatari M, Takeshita N, Hayakawa K, Kanagawa S, Ohmagari N (2014). Two cases of Zika fever imported from French Polynesia to Japan, December 2013 to January 2014. Euro Surveill. 19: pii=20683.

18- Lucchese G, Kanduc D (2016).Zika virus and autoimmunity: From microcephaly to Guillain-Barré syndrome, and beyond. Autoimmun Rev. Mar 25. pii: S1568-9972(16)30077-5. doi: 10.1016/j.autrev.2016.03.020. [Epub ahead of print]

19- Miranda-Filho Dde B, Martelli CM, Ximenes RA et al (2016). Initial description of the presumed congenital Zika syndrome. Am J Public Health Apr;106(4):598-600. doi: 10.2105/AJPH.2016.303115.

20- Musso D, Nhan T, Robin E, Roche C, Bierlaire D, Zisou K, Shan Yan A, Cao-Lormeau VM, Broult J (2014). Potential for Zika virus transmission through blood transfusion demonstrated during an outbreak in French Polynesia, November 2013 to February 2014. Euro Surveill. 9:pii=20761.

21- Musso D, Roche C, Nhan TX, Robin E, Teissier A, Cao-Lormeau VM (2015). Detection of Zika vírus in saliva. Clin Virol 68: 53-55.

Doi:10.1016/j.jcv.2015.04.021. Epub 2015 Apr 29.

22- Oehler E, Watrin L, Larre P, Leparc-Goffart I, Lastère S, Valour F, Baudouin L, Mallet HP, Musso D, Ghawche F (2014). Zika virus infection complicated by Guillain-Barré syndrome - case report, French Polynesia, December 2013. Euro Surveill 19: pii=20720.

23- Oliveira Melo AS, Malinger G, Ximenes R, Szejnfeld PO, Alves Sampaio S, Bispo de Filippis AM (2016). Zika virus intrauterine infection causes fetal brain abnormality and microcephaly: tip of the iceberg? Ultrasound Obstet Gynecol 47: 6-7. Doi: 10.1002/uog.15831.

24- Rasmussen SA, Jamieson DJ, Honein MA, Petersen LR. Zika Virus and Birth Defects - Reviewing the Evidence for Causality. N Engl J Med. 2016 Apr 13. [Epub ahead of print] PubMed PMID: 27074377.

25- Scully C, Robinson A (2016). Check before you traval: Zika virus another emerging global health threat. Br Dent J. 11;220(5):265-7.

26- Shakib K (2016). Epidemic of Zika virus and maxillofacial surgery. Br J Oral Maxillofac Surg. 2016 Feb 19. pii: S0266-4356(16)00058-9. doi: 10.1016/j.bjoms.2016.02.001. [Epub ahead of print]. 
27- Tappe D, Rissland J, Gabriel M, Emmerich P, Günther S, Held G, Smola S, Schmidt-Chanasit J (2014). First case of laboratory-confirmed Zika virus infection imported into Europe, November 2013. Euro Surveill. 19: pii=20685. 28- Willison HJ, Jacobs BC, van Doorn PA (2016). Guillain-Barré syndrome. Lancet. Feb 29. pii: S0140-6736(16)00339-1. doi: 10.1016/S01406736(16)00339-1. [Epub ahead of print] Review. PubMed PMID: 26948435. 
Table 1 Shepards Criteria for teratogenicity (Rasmussen et al., 2016)

\begin{tabular}{|c|c|c|c|}
\hline $\begin{array}{l}\text { Criterion } \\
\text { Number }\end{array}$ & Criterion & Evidence & $\begin{array}{l}\text { Criterion } \\
\text { Met? }\end{array}$ \\
\hline 1 & $\begin{array}{l}\text { Proven exposure to } \\
\text { the agent at one or } \\
\text { more critical times } \\
\text { during prenatal } \\
\text { development }\end{array}$ & $\begin{array}{l}\text { On the basis of case reports, case series and } \\
\text { epidemiologic studies of microcephaly that are } \\
\text { associated with laboratory-confirmed or } \\
\text { presumed ZIKV infection, the timing of ZIKV } \\
\text { virus infection associated with severe } \\
\text { microcephaly and intracranial calcifications } \\
\text { appears to be in the late first or early second } \\
\text { trimester }\end{array}$ & Yes \\
\hline 2 & $\begin{array}{l}\text { Consistent findings } \\
\text { by } 2 \geq \text { high-quality } \\
\text { epidemiologic } \\
\text { studies, with control } \\
\text { of confounding } \\
\text { factors, sufficient } \\
\text { numbers, exclusion } \\
\text { of positive and } \\
\text { negative bias factors, } \\
\text { prospective studies if } \\
\text { possible, and relative } \\
\text { risk } \geq 6\end{array}$ & $\begin{array}{l}\text { On the basis of data from Brazil, temporal and } \\
\text { geographic association between ZIKV illness } \\
\text { and cases of microcephaly is strong. Two } \\
\text { epidemiologic studies have been published. In a } \\
\text { study in Brazil, that used a prospective cohort } \\
\text { design, } 29 \% \text { of women with ZIKV infection at } \\
\text { any time during pregnancy had abnormalities } \\
\text { on prenatal ultrasonography, some of which } \\
\text { have not been confirmed postnatally. Ina study } \\
\text { in French Polynesia, retrospective identification } \\
\text { of eight cases of microcephaly and the use of } \\
\text { serologic and statistical data and mathematical } \\
\text { modeling suggested that } 1 \% \text { of foetuses and } \\
\text { infants born to women with ZIKV infection } \\
\text { during the first trimester had microcephaly; the } \\
\text { risk ratio in this analysis was approximately } 50 \text {, } \\
\text { as compared with the baseline prevalence of } \\
\text { microcephaly. } \\
\text { No other epidemiologic studies have examined } \\
\text { this association to date. }\end{array}$ & Partially \\
\hline 3 & $\begin{array}{l}\text { Careful delineation of } \\
\text { clinical cases; a } \\
\text { specific defect or } \\
\text { syndrome, if present, } \\
\text { is very helpful }\end{array}$ & $\begin{array}{l}\text { The phenotype has been well characterised in } \\
\text { foetuses and infants with presumed congenital } \\
\text { ZIKV infection, including microcephaly and } \\
\text { other serious brain anomalies, redundant scalp } \\
\text { skin, eye findings, arthrogryposis and clubfoot. } \\
\text { The phenotype in some infants appears to be } \\
\text { consistent with the foetal brain disruption } \\
\text { sequence, which has been observed after } \\
\text { infection with other viral teratogens. }\end{array}$ & Yes \\
\hline 4 & $\begin{array}{l}\text { Rare environmental } \\
\text { exposure that is } \\
\text { associated with rare } \\
\text { defect }\end{array}$ & $\begin{array}{l}\text { Reports of foetuses and infants with } \\
\text { microcephaly who are born to women with brief } \\
\text { periods of travel to countries with active ZIKV } \\
\text { transmission are consistent with ZIKV being a } \\
\text { rare exposure. } \\
\text { The defect, congenital microcephaly, is rare, } \\
\text { with a birth prevalence of approximately } 6 \\
\text { cases per } 10,000 \text { live born infants, according to }\end{array}$ & Yes \\
\hline
\end{tabular}




\begin{tabular}{|c|c|c|c|}
\hline & & $\begin{array}{l}\text { data from birth-defects surveillance systems in } \\
\text { the United States. }\end{array}$ & \\
\hline 5 & $\begin{array}{l}\text { Teratogenicity in } \\
\text { experimental animals } \\
\text { important but not } \\
\text { essential }\end{array}$ & $\begin{array}{l}\text { No results of an animal model with ZIKV } \\
\text { infection during pregnancy and foetal effects } \\
\text { have yet been published. }\end{array}$ & No \\
\hline 6 & $\begin{array}{l}\text { Association should } \\
\text { make biologic sense }\end{array}$ & $\begin{array}{l}\text { Findings are similar to those seen after prenatal } \\
\text { infection with some other viral teratogens (eg } \\
\text { rubella virus, cytomegalovirus). } \\
\text { Animal models have shown that ZIKV is } \\
\text { neurotropic, which supports biologic plausibility. } \\
\text { Evidence that ZIKV infects neural progenitor } \\
\text { cells and produces cell death and abnormal } \\
\text { growth, along with evidence of ZIKV in brains of } \\
\text { foetuses and infants with microcephaly, on the } \\
\text { basis of immunohistochemical staining and } \\
\text { identification of ZIKV RNA and live virus, } \\
\text { provides biologic plausibility. }\end{array}$ & Yes \\
\hline 7 & $\begin{array}{l}\text { Proof in an } \\
\text { experimental system } \\
\text { that the agent acts in } \\
\text { an unaltered state } \\
\end{array}$ & $\begin{array}{l}\text { The criterion applies to a medication or } \\
\text { chemical exposure, not to infectious agents. }\end{array}$ & NA \\
\hline
\end{tabular}

* Criteria 1,2 and 3 or criteria 1, 3 and 4 are considered to be essential, whereas criteria 5,6 and 7 are helpful but not essential. Partial evidence is insufficient to meet a criterion. ZIKV - Zika virus; NA - not applicable 
Table 2. Countries with confirmed local transmission of ZIKV (to April/2016).

\begin{tabular}{|c|c|c|c|c|c|}
\hline North America & South America & Central America & Asia & Europe & Ocean \\
\hline $\begin{array}{c}\text { Mexico } \\
\text { Canada } \\
\text { United States }\end{array}$ & $\begin{array}{c}\text { Brazil } \\
\text { Colombia } \\
\text { Venezuela } \\
\text { Bolivia } \\
\text { Argentina } \\
\text { French Guiana } \\
\text { Peru } \\
\text { Suriname } \\
\text { Chile }\end{array}$ & $\begin{array}{c}\text { Haiti } \\
\text { El Salvador } \\
\text { Panama } \\
\text { Honduras } \\
\text { Martinique } \\
\text { Puerto Rico } \\
\text { Belize } \\
\text { Costa Rica } \\
\text { Republic of } \\
\text { Trinidad and } \\
\text { Tobago } \\
\text { Aruba } \\
\text { Curacao } \\
\text { Saint Maarten } \\
\text { U.S. Virgin } \\
\text { Islands } \\
\text { Barbados } \\
\text { Dominican } \\
\text { Republic } \\
\text { Nicaragua } \\
\text { Jamaica } \\
\text { Bonaire } \\
\text { Saint Vincent } \\
\text { and the } \\
\text { Grenadines } \\
\text { Cuba } \\
\text { Dominica } \\
\text { Saint Lucia }\end{array}$ & $\begin{array}{c}\text { Bangladesh } \\
\text { Vietnam } \\
\text { Philippines } \\
\text { New Caledonia } \\
\text { Laos }\end{array}$ & $\begin{array}{c}\text { Portugal } \\
\text { Italy } \\
\text { France }\end{array}$ & Papua New \\
\hline
\end{tabular}


Figure 1. The ZIKV virus, which is commonly found in parts of Africa and South East Asia spread to Latin America via French Polynesia. Last year more than 1.5 million people in South America became infected, before the virus spread to the Caribbean, Mexico and Texas towards the end of 2015 (Published: 13:53 GMT, 5 February 2016, Daily Mail)

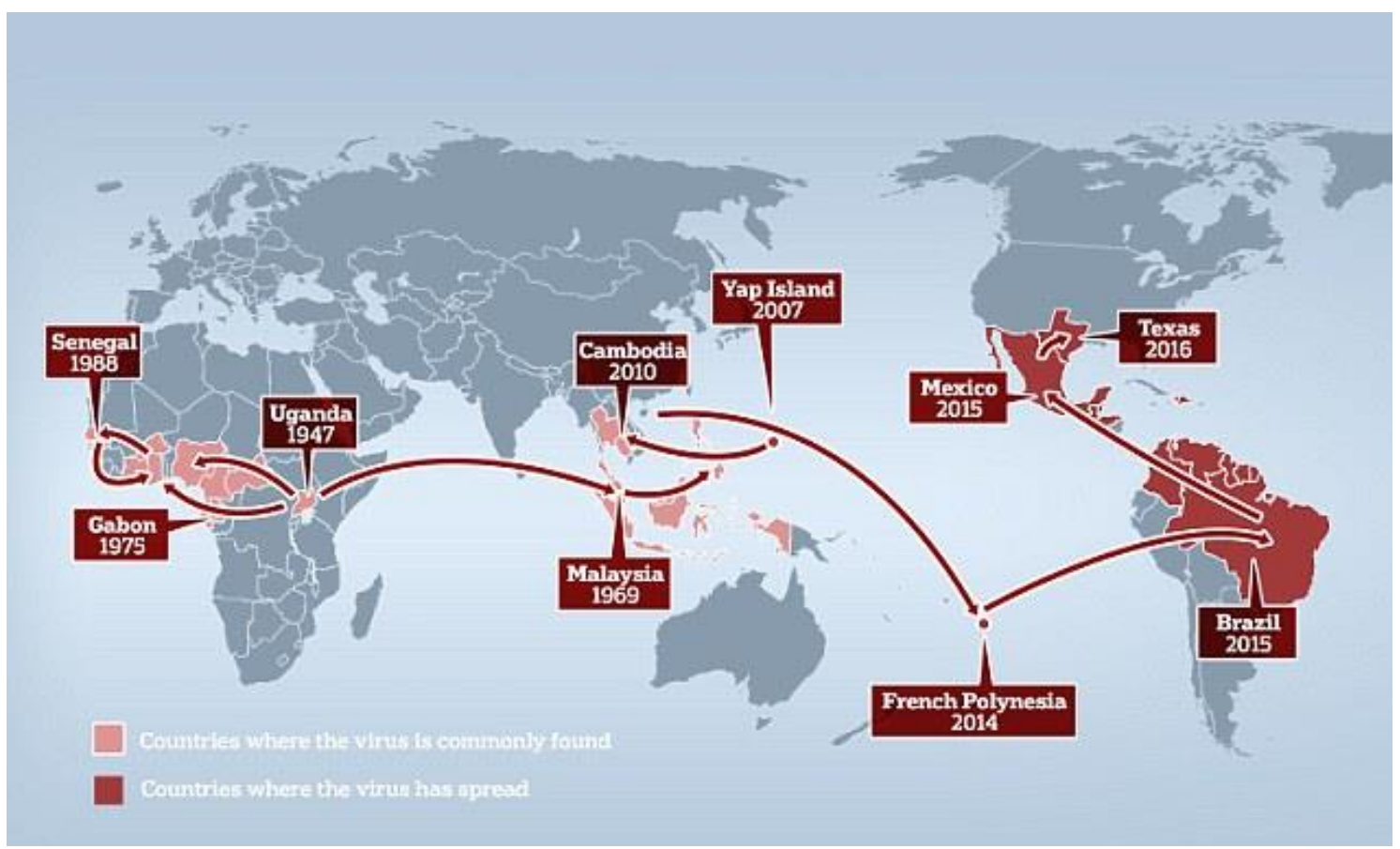

